ISSN: 2277-3754

ISO 9001:2008 Certified

International Journal of Engineering and Innovative Technology (IJEIT)

Volume 10, Issue 3, September 2020

\title{
Effect of the decisive elements in the material
} management technology

Olanrewaju Sharafadeen Babatunde Owolabi and Oyebiyi Simeon Abiodun

Department of Building Technology, School of Environmental Studies, The Federal Polytechnic, Ado Ekiti, Ekiti State, Nigeria.

\begin{abstract}
It is apparent that effective and efficient material management will reduce the problem of unnecessary material wastage, scarcity of material, cost-overrun and time-overrun. The research centred on the factors affecting the material management strategies of construction works. This study examined the existing strategies of materials supervision on building projects, the challenges of materials management and material management steps for construction projects in the state of Ekiti. This research was carried out by conducting questionnaires and evaluated by means of a Relative Significance Index (RSI) for professionals in advising and contracting firms. The analysis showed that material distribution sequence was graded as one at the rate of RSI 1,003, followed by local supply and weak preparation and coordination with the values of RSI of 0.79 (79\%) and 0.74 (74\%) respectively. Damage of material in storage was ranked least with the RSI value of 0.597 (59.7\%).The study recommends that there must be sequence of materials delivery to avoid waste and theft, the construction materials must be readily available within the surroundings, stringent laws to eliminate quack/sharp practices and promote professionalism in design and construction works should be enacted and religiously enforced, there must be adequate planning and coordination and there must be good and effective communication among site workers.
\end{abstract}

Keywords: building, construction, management, material, strategies.

\section{INTRODUCTION}

Material management is important because many issues come up on construction site like non-availability of material, inadequate storage, lack of proper handling, and late delivery of materials, etc, which results in cost overrun and time teeming, and perhaps abandonment of building plan. The problem of excessive waste, material shortage, overhead and time overrun is clearly reduced through efficient and effective management of materials. [1]

Unique material management functions include the preparation and disposal of materials, the assessment of suppliers, the procurement of materials, purchases, delivery, receiving materials, storage and storage and distribution of materials. Materials management is a scheduled process which involves buying, shipping, handling and minimising waste in order to ensure that project requirements are fulfilled. [2] indicate that a large number of contractors operating in the Nigerian construction sector do not participate in any form of quantitative construction planning, but prefer to be based on "intuitive" project management (hunches or previous experience).

Manuscript received: 19 August 2020

Manuscript received in revised form: 17 September 2020

Manuscript accepted: 02 October 2020

Manuscript Available online: 15 October 2020
If material management is a planning process as defined earlier, invariably the need for awareness in eradicating unacceptable practices in order to move the Nigerian construction industry forward is a vital necessity. Material management is an approach to the planning, coordination and monitoring of activities related to material flow into the coordination. The scope of material management varies widely between businesses. Material planning and control, production planning, buying, inventory control, the transfer of inhouse waste materials and waste management can include this. It is an operational feature for the optimum planning, procurement, transfer and storage of material that helps organisations to reduce the various costs such as inventory, purchasing, material management and distribution. Building materials represent about $60 \%$ of total project cost and $80 \%$ of the project schedule are regulated. Based on $5.5 \%$ benefit from project costs, a $2 \%$ decrease in material costs would make $21 \%$ more profitable [3]. Stock supply, increased labour efficiency and decreased stock surpluses are benefits of a material management system. [1] Recall that incorporating the ICTs in material management and practises would substantially reduce unnecessary costs and improve efficiency in any project. There is a need for ICTs focused on material management practises in the construction industry, and there is significant interrelationship between relevant players in building, and their management can directly impact time, costs, quality and morality on project performance.

\section{LITERATURE REVIEW}

The management of materials provides a planning, organization and monitoring approach for all of those activities which mainly involve material flow into an organisation. It is a business feature for optimum preparation, procurement, transfer, storage of material that allows the company to minimise various costs such as inventory, procurement, handling of materials and distribution. The design and monitoring of functions supporting the entire content cycle (flow) and the related knowledge flow. These functions include: classify, catalogue, standardise, classify, schedule, purchase, inspect, monitor quality, box, storage, inventory control, delivery and disposal. Often named preparation products The importance of good management of the material is emphasised by the fact that the materials account for significant portions of project cost and time listed in [4], the management of the materials is characterised as a 
ISSN: 2277-3754

ISO 9001:2008 Certified

International Journal of Engineering and Innovative Technology (IJEIT)

Volume 10, Issue 3, September 2020

system of management that is essential to schedule and track the quality and quantities, the placing of timely materials, the good prices and the appropriate quantity.

The management of materials is characterised as a role to coordinate the planning and control of the flow of materials. In a comprehensive perspective, the management of materials is a scheduled process involving the procurement, supply, handling and minimal waste, to ensure that the specifications specified by [6] are met and that material waste is an additional expense, in addition to the used equipment, plus handling as provided for in the estimated job price. [4] was of the view that, when and in compliance with the minimum cost construction process, management of materials could be defined as the planning process, execution and control of the correct source of materials of exact quality. Material management may also be called quality management, since it minimises the cost impact of material on the execution of projects. [4] Considered that a material cost management goal is the early identification of any potentiacost deviation in the budget (cost overrun) for the purpose of taking corrective steps in compliance with forecasts. Similarly [6] expressed the view that the aim of material cost inspection is to require scheduled and scheduled materials.

\section{FACTORS THAT AFFECT THE MATERIAL MANAGEMENT STRATEGIES OF CONSTRUCTION WORKS}

The management of materials is a mechanism for the preparation, execution and control of building and office operations. The purpose of material management is to ensure that building materials are available when necessary at their point of use[5].It was observed that there are many factors that were identified among other factors that affect the material management strategies of construction works include sequence of materials delivery, availability of material in the local market, material changes in type and specification during construction, damage of material in storage, delay in the especial manufacture of building materials. unreliable supply from material suppliers, poor planning and coordination, poor communication between sites, inadequate waste management plan, transportation for large quantities, inadequate knowledge of IT solution on materials management, improper handling on site/manual materials handling, workers' mistakes/misuse of specification, excessive paper work, management of surplus materials, dispute resolution strategies and lack of skilled negotiating procedures. Project materials management practises are classified as practises in five areas [6]: planning, sourcing, transport, handling and waste management.

\section{RESEARCH METHODOLOGY}

A well organised sixty (60) questionnaires were administered on contractors in selected construction firms in Ekiti State in order to appraise the factors that affect the material management strategies of construction works.

The collected data was tabled and the analytics were performed using basic statistical tools to include percentages among other methods. In the third institutions in Nigeria, data obtained from different professionals within the built environment were analysed by using the arithmetic mean and the ranking of the statistical study by decreasing value method For evaluation purposes the average scoring was used to investigate the causes, consequences and potential corrective activities and the observations from which conclusions were drawn. The results were identified. The following formulation was used to measure the arithmetic mean:

Mean score $=\frac{\sum W_{i} f_{i}}{\sum f_{i}}=\frac{1 a+2 b+2 c+4 d+5 e}{N j}$

Where $\Sigma w_{i}=$ the summation of the weights.

$$
\sum f_{i}=\text { the summation of responses }
$$

The factors were measured by using theLikert level linking rating on gap scale of 5 and 1 which was developed for submission in public sciences and organization researches for quantification of qualitative variable be used, namely:

5 represent "Extremely important (EI),"

4 represent "Very important (VI),"

3 represent "Somewhat important (SI),"

2 represent "Not very important (NVI),"

1 represents "Not important (NI)."

\section{DATA PRESENTATION AND ANALYSIS}

This study was focused on three major influencing factors affecting the material management techniques that are then described and described within the factors identified.

Table 1: Respondents' Gender

\begin{tabular}{ccc}
\hline Gender & Frequency & Percent \\
\hline Male & 41 & 68.33 \\
Female & 19 & 31.67 \\
\hline Total & $\mathbf{6 0}$ & $\mathbf{1 0 0 . 0}$ \\
\hline
\end{tabular}

Table 1 shows respondents' gender. It showed that 68.33

(41) percent of the respondents are males and 31.67 percent (19) are females.

Table 2: Professional body you belong to in the Construction Industry

\begin{tabular}{lll}
\hline Professional body & Frequency & Percent \\
\hline NIQS & 12 & 20 \\
NIOB & 27 & 45 \\
\hline
\end{tabular}


ISSN: 2277-3754

ISO 9001:2008 Certified

International Journal of Engineering and Innovative Technology (IJEIT)

Volume 10, Issue 3, September 2020

\begin{tabular}{lll}
\hline NIA & 8 & 13.33 \\
Others & 13 & 21.67
\end{tabular}

\begin{tabular}{lll}
\hline Total & 60 & 100.0
\end{tabular}

Table 2 shows the professional bodies that the respondents are associated with. It showed that 45 percent (27) are members of the Nigerian Institute of Builders (NIOB), 20 percent 12 are members of the Nigerian Institute of Quantity Surveyors (NIQS), and 13.33 percent (8) are members of the Nigerian Institute of Architects (NIA), while 21.67 percent (13) belong to RSI = Relative Significance Index, TWV = Total Weight Value.

Table 3 shows the factors that affect the material management strategies of construction works. It shows that sequence of materials delivery ranked first with RSI value of 1.003 followed by availability of material in the local market, and poor planning and co-ordination with RSI values of $0.79(79 \%)$ and $0.74(74 \%)$ respectively. Damage of material in storage was ranked least with the RSI value of $0.597(59.7 \%)$. other related professional bodies such as Nigerian Society of Engineers and so on.

Table 3: Factors that Affect the Material Management Strategies of Construction Works

\begin{tabular}{|c|c|c|c|c|c|c|c|c|c|c|}
\hline $\mathbf{S} / \mathbf{N}$ & FACTORS & 1 & 2 & 3 & 4 & 5 & TOTAL & TWV & RSI & RANK \\
\hline 1 & Sequence of materials delivery & 5 & 3 & 1 & 22 & 29 & 60 & 301 & 1.003 & $\overline{1}$ \\
\hline 2 & Availability of material in the local market & 6 & 2 & 5 & 23 & 24 & 60 & 237 & 0.790 & 2 \\
\hline 3 & $\begin{array}{l}\text { Material changes in type and specification during } \\
\text { construction }\end{array}$ & 9 & 2 & 10 & 28 & 11 & 60 & 210 & 0.700 & 7 \\
\hline 4 & Damage of material in storage & 10 & 12 & 13 & 19 & 6 & 60 & 179 & 0.597 & 15 \\
\hline 5 & $\begin{array}{l}\text { Delay in the especial manufacture of building } \\
\text { materials }\end{array}$ & 9 & 11 & 9 & 22 & 9 & 60 & 191 & 0.637 & 14 \\
\hline 6 & Unreliable supply from material suppliers & 8 & 9 & 10 & 21 & 12 & 60 & 200 & 0.667 & 12 \\
\hline 7 & Poor planning and co-ordination & 7 & 8 & 7 & 12 & 26 & 60 & 222 & 0.740 & 3 \\
\hline 8 & Poor communication between sites & 12 & 5 & 7 & 14 & 22 & 60 & 209 & 0.697 & 8 \\
\hline 9 & Inadequate waste management plan & 10 & 6 & 13 & 23 & 8 & 60 & 193 & 0.643 & 13 \\
\hline 10 & Transportation for large quantities & 11 & 3 & 1 & 28 & 17 & 60 & 217 & 0.723 & 5 \\
\hline 11 & $\begin{array}{l}\text { Inadequate knowledge of IT solution on materials } \\
\text { management }\end{array}$ & 12 & 2 & 11 & 22 & 13 & 60 & 202 & 0.673 & 11 \\
\hline 12 & $\begin{array}{l}\text { Improper handling on site/manual materials } \\
\text { handling }\end{array}$ & 10 & 2 & 10 & 18 & 20 & 60 & 216 & 0.720 & 6 \\
\hline 13 & Workers' mistakes/misuse of specification & 8 & 4 & 10 & 17 & 21 & 60 & 219 & 0.730 & 4 \\
\hline 14 & Excessive paper work & 11 & 5 & 14 & 20 & 10 & 60 & 193 & 0.643 & 13 \\
\hline 15 & Management of surplus materials & 9 & 6 & 8 & 23 & 14 & 60 & 207 & 0.690 & 9 \\
\hline 16 & Dispute resolution strategies & 10 & 3 & 11 & 23 & 13 & 60 & 206 & 0.687 & 10 \\
\hline 17 & Lack of skilled negotiating procedures & 10 & 2 & 13 & 19 & 16 & 60 & 209 & 0.697 & 8 \\
\hline
\end{tabular}

\section{DISCUSSION OF FINDINGS}

Workers' mistakes/misuse of specification with RSI value of $0.73(73 \%)$, transportation for large quantities with RSI value of 0.723 (72.30\%), improper handling on site/manual materials with RSI value of $0.72(72 \%)$. Material changes in type and specification during construction with RSI value of 0.70 (70\%). Poor communication between sites and lack of skilled negotiating procedures ranked eighth with RSI value of $0.697(69.70 \%)$ followed by management of surplus materials with RSI value of 0.69 (69\%), dispute resolution strategies with RSI value 0.687 (68.70), inadequate knowledge of IT solution on materials management with RSI value of $0.673 \quad(67.30 \%)$, unreliable supply from material suppliers with RSI value of $0.667(66.70 \%)$ while inadequate waste management plan and excessive paper work ranked thirteenth with RSI value of 0.643 (64.30). Delay in the especial manufacture of building materials ranked fourteenth with RSI value of $0.637(63.70 \%)$ and damage of material in storage was ranked least with the RSI value of 0.597 (59.7\%).

\section{CONCLUSION AND RECOMMENDATION A. CONCLUSION}

There must be sequence of materials delivery to avoid waste and theft. The construction materials must be readily available within the surroundings, stringent laws 
ISSN: 2277-3754

ISO 9001:2008 Certified

International Journal of Engineering and Innovative Technology (IJEIT)

\section{Volume 10, Issue 3, September 2020}

to eliminate quack/sharp practices and promote professionalism in design and construction works should be enacted and religiously enforced, there must be adequate planning and co-ordination and there must be good and effective communication among site workers.

The findings revealed that sequence of materials delivery, availability of material in the local market, material changes in type and specification during construction, damage of material in storage, delay in the especial manufacture of building materials. unreliable supply from material suppliers, poor planning and coordination, poor communication between sites, inadequate waste management plan, transportation for large quantities, inadequate knowledge of IT solution on materials management, improper handling on site/manual materials handling, workers' mistakes/misuse of specification, excessive paper work, management of surplus materials, dispute resolution strategies and lack of skilled negotiating procedures are the factors that affect the material management strategies of construction works.

\section{B. RECOMMENDATIONS}

Based on the findings of this research and a review of previous research, the following recommendations were made:

i. There must be sequence of materials delivery to avoid waste and theft.

ii. The construction materials must be readily available within the surroundings.

iii. Stringent laws to eliminate quack/sharp practices and promote professionalism in design and construction works should be enacted and religiously enforced.

iv. There must be adequate planning and coordination.

v. For the successful construction work there must be good and effective communication among site workers.

\section{REFERENCES}

[1] N.B.Kasim, C. J. Anumba and A.R. Dainty, "Improving Materials Management Practices on Fast-Track Construction Projects", Journal of Construction Management and Engineering, 24, pp: 206-213, 2005.

[2] A. Veronica, S. L.Riantini, and B. Trigunarsyah, "Corrective Action Recommendation for Project Cost Variance in Construction Material Management", The Tenth East Asia-Pacific Conference on Structural Engineering and Construction 05, Bangkok, Thailand, pp: 23-28, 2006.

[3] N. B. Kasim and P. A.Soon Ern,"The awareness of ICT Implementation for Material Management in Construction Projects". Journal of Construction Engineering and project management, pp: 31-36, May 2011.

[4] Y. Latif, I. Abiding, and B. Trigunarsyah, "KnowledgeBased Material Cost Control for Building Construction Project using Expert System Approach". In the Proceedings of CIB International Conference on Building
Education and Research, School of the Built Environment, University of Salford, Salford, UK. pp: 1969-1978, 2008.

[5] P. O. Akanni, A. E. Oke, and O. J. Omotilewa, "Implications of Rising Cost of Building Materials in Lagos State Nigeria", Sage Open Journal, pp:1-7, OctoberDecember 2014.

[6] A. Gulghane and P. V. Khandve," Management for Construction Materials and Control of Construction Waste in Construction Industry: A Review", Int. Journal of Engineering Research and Applications, vol. 5, Issue 4, pp. 59-64, 2015. 